\title{
PANDANGAN HAKIM PA SE D.I YOGYAKARTA TERHADAP COUNTER LEGAL DRAF KOMPILASI HUKUM ISLAM (CLD-KHI)
}

\author{
Iri Hamzah \\ Institut Agama Islam Yasni Bungo \\ Email: erihamzah80@gmail.com
}

\begin{abstract}
The emergence of the CLD-KHI formula with a number of crucial articles as a renewal of Islamic family law becomes interesting to discuss. The amount of opposition and resistance to this formulation has made it always studied and explored by a number of groups, although it still causes controversy and disputes. In practice, PA judges make KHI a material law in every decision, although not all sourced from KHI. This is what some consider that KHI actually has weaknesses, so it is not relevant to apply today. Then came the match, namely CLD-KHI. PA judges' views on CLD-KHI are interesting to discuss. It can not be separated from several reasons including: First, the CLD-KHI articles are closely related to the KHI articles. The second CLD KHI has a goal and vision that is similar to KHI even though it gives rise to controversy. third for some people CLD-KHI has been believed to be in accordance with Maqashid ash-shari'ah.
\end{abstract}

Keywords: Counter legal Draft (CLD), Compilation of Islamic Law, Religion Court and Judge

\begin{abstract}
Abstrak
Munculnya rumusan CLD-KHI dengan sejumlah pasal krusial sebagai pembaruan hukum keluarga Islam menjadi menarik untuk diperbicangkan. Banyaknya pertentangan dan perlawanan terhadap rumusan ini menjadikannya selalu dikaji dan ditelaah oleh sejumlah kalangan, walaupun masih menimbulkan kontroversi dan perdebatan. Di dalam prakteknya hakim PA menjadikan KHI sebagai hukum materil dalam setiap putusannya, walaupun tidak semua bersumber dari KHI. Hal inilah yang oleh sebagian kalangan menilai bahwa KHI sejatinya memilki kelemahan, sehingga tidak relevan diterapkan masa kini. Maka muncullah tandingannya yaitu CLD-KHI. Pandangan hakim PA terhadap CLD-KHI menjadi menarik untuk diperbincangkan. Hal tidak lepas dari beberapa alasan di antaranya adalah: Pertama, Pasal-pasal CLDKHI berkaitan erat dengan pasal-pasal KHI, kedua CLD KHI memiliki tujuan dan visi yang sema dengan KHI walaupun melahirkan kotroversi, ketiga untuk kalangan tertentu CLD-KHI telah diyakini sesuai dengan Maqashid asy-syari’ah.
\end{abstract}

Kata Kunci: Counter legal Draft (CLD), Kompilasi Hukum Islam (KHI), Pengadilan Agama dan Hakim

Nur El-Islam, Volume 6, Nomor 1, April 2019 


\section{A. Pendahuluan}

Ditengah derasnya perdebatan tentang formalisasi hukum Syariat Islam ini, Departemen Agama melalui Direktorat Pembinaan Badan Peradilana Agama (Ditbinpera) pada tanggal 27 September 2002 membentuk sebuah badan yang disebut Badan Pengkajian dan Pengembangan Hukum Islam (BPPHI). Badan ini sengaja dibentuk untuk merealisasikan amanat UU Nomor 25 Tahun 2000 tentang Program Pembangunan Nasional (Propenas) tahun 2000-2004, UU ini menegaskan bahwa salah satu elemen kesuksesan pemerintah dalam bidang penegembangan hukum adalah adanya hukum subtantif peradilan agama. Dengan kata lain, pemerintah harus mengupayakan peningkatan status hukum KHI dari Inpres menjadi Undang-undang. ${ }^{1}$

Melalui surat keputusan Menteri Agama Nomor 416 tanggal 27 September 2000, Badan ini dipimpin oleh Taufik Kamil (Direktur Jendral Bimbingan Islam dan Urusan Haji) serta Mochtar Zarkasyi (mantan Direktur Pembinaan Badan Peradilan Agama) dan Rifyal Ka'bah (Hakim Agung) sebagai wakilnya. Sejumlah pakar hukum Islam juga dilibatkan dalam badan ini, di antaranya adalah Busthanul Arifin (mantan Hakim Agung), Abdul Gani Abdullah (Direktur Jenderal Hukum Departemen Kehakiman saat itu), Ichtijanto (mantan direktur Pembinaan Peradilan Agama), Taufik (wakil ketua mahkamah agung periode tersebut), KH. MA Sahal Mahfudz ketua Umum MUI, Rais Syuriaah PBNU), Ismail Sunny (Guru Besar Ilmu Hukum UI Jakarta), Faisal Ismail (Sekretaris Jendral Depag saat itu) dan Menteri Agama sendiri, Said Aqil Husein Al-Munawwar. ${ }^{2}$

Pokja PUG Depag, melalui Tim Pembaruan KHI menyusun CLDKHI, yang terdiri dari RUU Hukum perkawinan Islam sebanyak 116 pasal, RUU Hukum Kewarisan Islam sebanyak 42 pasal, dan RUU

${ }^{1}$ Marzuki Wahid, Fiqh Indonesia Kompilasi Hukum Counter Legal Draft, (Bandung, Marja, 2014), h. 133.

${ }^{2}$ Said Aqil Husein Al-Munawwar adalah Menteri Agama pada kabinet Gotong Royong (2001-2004). Ia lahir di Palembang, 26 Januari 1954, sebelumnya dia menjadi dosen UIN Jakarta, lulusan doktor dari Fakultas Syariah di Universitas Ummul al-quro' Makkah Arab Saudi 1987). Lihat di Marzuki Wahid, Fiqh Indonesia Kompilasi Hukum Counter Legal Draft, (Bandung, Marja, 2014), h. 134 
Perwakafan Islam sebanyak 20 pasal. CLD-KHI sesungguhnya kritik terhadap hukum keluarga Islam Indonesia yang dilakukan oleh banyak kalangan. Hal ini sebenarnya pernah terjadi tetapi belum ada pihak yang serius dan sistematik melakukan rekonstruksi dan perumusan ulang terhadap hukum keluarga Islam yang di dalamnya mencakup keadilan gender, HAM, pluralisme, menjunjung tinggi nilai-nilai kemanusiaan dan demokratis. ${ }^{3}$

Tim Pengarusataman gender menilai bahwa KHI yang selama ini digunakan mengandung paling tidak 19 isu krusial, di antaranya masalah pengertian perkawinan, wali nikah, pencatatan perkawinan, batas usia perkawinan, mahar, kawin beda agama, bagian anak lakilaki dan perempuan, wakaf beda agama, anak di luar nikah, dan soal aul dan radd. Inilah ke 19 isu krusial yang menjadi tawaran baru dalam CLD-KHI. ${ }^{4}$ Rumusan ini didasarkan pada penafsiran atas al-Qur'an, alHadits, dan pendapat ulama fiqh dengan kemaslahatan, maqashid alsyari'ah, akal publik, dan kearifan lokal. Penalarannya menggunakan perspektif demokrasi, pluralisme, hak asasi manusia, dan keadilan gender pada lanskap realitas keindonesiaan. ${ }^{5}$

\section{B. Pembahasan}

\section{Alur Penafsiran CLD-KHI}

Berbasiskan naskah KHI, tim CLD KHI mengubah kerangka berfikir pembentukan hukum Islam" dalam teosentrisme ke antroposentrisme dari elitis ke populis, dari deduktif ke induktif dan dari eisegese ke exegese ${ }^{6}$ hal ini dilakukan karena mempertimbangkan

\footnotetext{
${ }^{3}$ Musdah Mulia, Muslimah Reformis, (Bandung, Mizan Pustaka, 2005), h. 391.

${ }^{4}$ Ibid., h. 392

${ }^{5}$ Ibid.
}

${ }^{6}$ Dalam buku pembaruan hukum Islam: Counter Legal Draft Kompilasi Hukum Islam dijelaskan "Eisegese adalah tindakan membawa masuk pikiran atau ideologinya sendiri ke dalam nash, lalu menariknya ke luar dan mengklaimnya sebagai maksud Tuhan" sedangkan exegese adalah tindakan para penafsir untuk berusaha semaksimal mungkin untuk menempatkan nash sebagai obyek” dan penafsir sebagai subjek “ dalam suatu dialektika yang seimbang, baca Tim Pengarusataman Gender Departemen Agama RI. Pembaruan Hukum Islam Counter Legal Draft Kompilasi Hukum Islam, Jakarta, 2004, h. 2223. 
realitas kebudayaan masyarakat Indonesia yang berbeda dengan arab dan timur tengah, juga memperhatikan kondisi banyak perempuan Indonesia yang dewasa ini mampu membiayai diri dan keluarga dari pekerjaan produktifnya dan banyak perempuan yang menjadi pemimpin publik, mulai dari kepala desa, kepala kepolisian hingga presiden.

CLD-KHI mencoba menafsirkan ayat alquran dan hadist dengan berbagai pendekatan di antaranya pendekatan kemashlahatan, kearifan lokal, maqashid al-syari'ah dan akal publik. Ini tercermin dari kaidah ushul fiqih yang digunakan dalam merumuskan ketentuan dalam kaidah-kaidah Islam. ${ }^{7}$

\section{Metodologi CLD KHI}

Pada umumnya proses legal drafting, CLD-KHI hadir melalui serangkaian kegiatan yang terkait dan dilakukan secara bertahap, sistematis, dan melibatkan sejumlah pihak yang berkompeten. Tim Pengarusataman gender merangkai dan merencanakan sejumlah aktifitas yang mereka lakukan dalam perumusan CLD-KHI. Dianataranya adalah (1) Review (mengkaji ulang) KHI, (2) studi literatur klasik Islam, (3) studi lapangan di lima daerah ( Sulawesi Selatan, Sumatra Barat, Jawa Barat, aceh, Nusa Tenggara Barat). (3) pengujian ilmiah dan penyerapan pendapat ulama dan ahli hukum, (4) desiminasi hasil dan pengujian publik. ${ }^{8}$

${ }^{7}$ Dia antaranya adalah [1) al-ibrah bi al-maqashid la bi al-afadh(pengambilan keputusan hukum dilakukan dari maqashid [tujuan-tujuan,konteks] yang dikandung, bukan dari huruf aksara ayat-ayat alquran atau hadist [2] jawaz al-naskh al-nushush bi almaslahat (ketentuan teks al-quran dan hadist dapat diganti/dihapus dengan logika kemashlahatan) [3] tanqih al-nushush bi al-aql al-mujatama'(akal publik memiliki kewenangan untuk mengamandemen teks-teks alquran dan hadist,[4] takhshish bi al-aql wa takhshish bi al-'urf (akal dan tradisi memilki kewenangan untuk mengkhususkan teks-teks alquran dan al-hadist, [5] al-ibroh bi khushush al-sabab la bi umum alfadh(pengambilan keputusan hukum terhadap teks selalu terkait dengan konteks turunya, bukan didasarkan pada keumumam teks al-quran dan hadist.) lihat Tim Pengarusataman Gender Departemen Agama RI, Pembaruan Hukum Islam Counter Legal Draft Kompilasi Hukum Islam, Jakarta, 2004, h. 23-24.

${ }^{8}$ Marzuki Wahid, Fiqh Indonesia Kompilasi Hukum Islam Dan Counter Legal Draft (Bandung, Marja, 2014), h. 232. 
Metodologi dan pandangan literalistik terhadap KHI terus mendapatkan pengukuhan dari kalangan Islam fundamentalis. Mereka selalu berupaya untuk menunndukkan realitas ke dalam kebenaran dogmatik nash,dengan pengabaian nyaris sempurna terhadap kenyataan konkrit di lapangan. Bahkan seringkali terjadi, mereka melakukan tindakan eisegese (membawa masuk pikiran atau ideologinya sendiri ke dalam teks). Bagi Musdah Mulia dan kawankawan, klaim semacam ini sangat berbahaya karena akan membuat umat Islam semakin eksklusif dalam pergaulan yang multireligius multikultural. Klaim-klaim semacam itu tidak berpengaruh positif apapun dalam usaha-usaha membangun kehidupan bersama yang toleran dalam masyarakat majemuk

\section{Pasal-Pasal Krusial CLD-KHI}

Naskah ini menurut Tim PUG, menawarkan sejumlah pemikiran pembaharuan hukum keluarga Islam, yang disusun dalam RUU Hukum perkawinan Islam, RUU Hukum Kewarisan Islam, dan RUU Hukum Perwakafan Islam. dari 178 pasal, ada 23 poin pemabaharuan hukum keluarga Islam versi CLD-KHI yang difokouskan dalam 3 bidang, yaitu Hukum Perkawinan, Hukum Kewarisan, dan Hukum Perwakafan. ${ }^{9}$ Dalam hal ini pendekatan yang dipakai adalah keadilan gender, HAM, pluralisme, demokrasi, dan memahami teks-teks alquran dan hadist, dan khazanah klasik intelektual Islam. ${ }^{10}$

Untuk mendapatkan gamabaran yang lengkap dan komperhensif, berikut akan penulis paparkan tentang perbedaan redaksi dan subtansi pasal-pasal krusial yang menjadi pokok-pokok pembahasan, baik dalam KHI maupun dalam CLD-KHI. Terdapat 18 pasal krusial dalam bidang hukum perkawinan Islam, 4 pasal dalam bidang hukum kewarisan Islam, dan 2 pasal dalam bidang hukum perawkafan. Menurut M. Sodik, pasal-pasal di atas bisa memunculkan isu krusial,

${ }^{9}$ Mufidah, Isu-isu Gender Kontemporer, (Malang, UIN-Maliki Press, 2010), h. 119.

${ }^{10}$ Marzuki Wahid, Fiqh Indonesia Kompilasi Hukum Islam Dan Counter Legal Draft (Bandung, Marja, 2014), h. 218. 
seperti isu diffable, ${ }^{11}$ karena berhubungan dengan persoalan HAM. Berikut ini bagan perbandingan pasal-pasal krusial CLD-KHI yaitu : ${ }^{12}$

Hukum Perkawinan

\begin{tabular}{|c|c|c|c|}
\hline No & Pembahasan & KHI Inpress - 1991 & CLD-KHI \\
\hline 1 & Perkawinan & Ibadah (pasal 2) & $\begin{array}{l}\text { Bukan ibadah tetapi } \\
\text { mua'malah (pasal 2) }\end{array}$ \\
\hline 2 & Wali nikah & $\begin{array}{l}\text { Rukun Nikah (pasal } \\
\text { 14) }\end{array}$ & $\begin{array}{l}\text { Bukan rukun nikah } \\
\text { (pasal 6) }\end{array}$ \\
\hline 3 & $\begin{array}{l}\text { Pencatatan } \\
\text { nikah }\end{array}$ & $\begin{array}{l}\text { Bukan rukun nikah } \\
\text { (pasal 14) }\end{array}$ & Rukun nikah (pasal 6) \\
\hline 4 & $\begin{array}{l}\text { Kesaksian } \\
\text { perempuan } \\
\text { dalam } \\
\text { perkawinan }\end{array}$ & $\begin{array}{l}\text { Perempuan tidak } \\
\text { boleh menjadi saksi } \\
\text { (pasal 25) }\end{array}$ & $\begin{array}{l}\text { Laki-laki dan } \\
\text { perempuan boleh } \\
\text { menjadi saksi (pasal } \\
\text { 11) }\end{array}$ \\
\hline 5 & $\begin{array}{l}\text { Batasasan } \\
\text { minimal usia } \\
\text { nikah }\end{array}$ & $\begin{array}{l}16 \text { tahun calon istri, } \\
19 \text { tahun calon } \\
\text { suami (pasal } 15 \text { ) }\end{array}$ & $\begin{array}{l}\text { Minimal } 19 \text { tahun bagi } \\
\text { laki-laki dan } \\
\text { perempuan (pasal 7) }\end{array}$ \\
\hline 6 & $\begin{array}{l}\text { Perkawinan } \\
\text { seorang } \\
\text { gadis } \\
\text { perawan } \\
\end{array}$ & $\begin{array}{l}\text { Usia berapapun gadis } \\
\text { dinikahkan dengan } \\
\text { walinya (pasal 14) }\end{array}$ & $\begin{array}{l}\text { Gadis pada usia } 21 \\
\text { tahun dapat } \\
\text { menikahkan dirinya } \\
\text { sendiri (pasal 7) }\end{array}$ \\
\hline 7 & Mahar & $\begin{array}{l}\text { Suami memberikan } \\
\text { mahar kepada istri } \\
\text { (pasal 30) }\end{array}$ & $\begin{array}{l}\text { Mahar bisa diberikan } \\
\text { dari suami ke istri atau } \\
\text { istri ke suami (pasal } \\
\text { 16) }\end{array}$ \\
\hline 8 & $\begin{array}{l}\text { Kedudukan } \\
\text { suami istri }\end{array}$ & $\begin{array}{l}\text { Suami adalah kepala } \\
\text { keluarga dan istri ibu } \\
\text { rumah tangga (pasal } \\
79 \text { ) }\end{array}$ & $\begin{array}{l}\text { Kedudukan,hak dan } \\
\text { kewajiban suami-istri } \\
\text { adalah seimbang (pasal } \\
\text { 49) }\end{array}$ \\
\hline
\end{tabular}

${ }^{11}$ Mochamad Sodik, Mencairkan kebakuan Fikih : Membaca KHI dan CLD-KHI bersama Musdah Mulia, dalam Jurnal As-Syir'ah vol.38, No.II, th. 2004, h. 205.

${ }^{12}$ Marzuki Wahid, Fiqh Indonesia Kompilasi Hukum Islam Dan Counter Legal Draft(Bandung, Marja, 2014), h. 221-224. Lihat juga di Mufidah, Isu-Isu Gender Kontemporer, (Malang, UIN-Maliki Press, 2010), h. 119-123. 


\begin{tabular}{|c|c|c|c|}
\hline 9 & $\begin{array}{l}\text { Pencarian } \\
\text { nafkah }\end{array}$ & $\begin{array}{l}\text { Kewajiban suami } \\
\text { (pasal } 80 \text { ayat } 4 \text { ) }\end{array}$ & $\begin{array}{l}\text { Kewajiban bersama } \\
\text { suami-istri (pasal } 51 \text { ) }\end{array}$ \\
\hline 10 & $\begin{array}{l}\text { Perjanjian } \\
\text { masa kawin }\end{array}$ & Tidak ada & $\begin{array}{l}\text { Diatur, sehingga } \\
\text { perkawinan putus } \\
\text { bersamaan dengan } \\
\text { berakhirnya masa } \\
\text { perkawinan yang telah } \\
\text { disepakati. (pasal } \\
22,28,56 \text { poin a) }\end{array}$ \\
\hline 11 & $\begin{array}{l}\text { Nikah beda } \\
\text { agama }\end{array}$ & Haram & $\begin{array}{l}\text { Mubah, selama } \\
\text { mencapai tujuan } \\
\text { perkawinan (pasal 54) }\end{array}$ \\
\hline 12 & Poligami & $\begin{array}{l}\text { Boleh dengan } \\
\text { sejumlah persyaratan } \\
\text { (pasal 55-59) }\end{array}$ & $\begin{array}{l}\text { Haram li ghairihi } \\
\text { (pasal 3) }\end{array}$ \\
\hline 13 & $\begin{array}{l}\text { Iddah atau } \\
\text { masa } \\
\text { tunggu, } \\
\text { masa transisi }\end{array}$ & $\begin{array}{l}\text { Hanya berlaku bagi } \\
\text { istri (pasal 153) }\end{array}$ & $\begin{array}{l}\text { Berlaku bagi suami- } \\
\text { istri ( Pasal 88) }\end{array}$ \\
\hline 14 & $\begin{array}{l}\text { Iddah akibat } \\
\text { perceraian }\end{array}$ & $\begin{array}{l}\text { Di dasarkan pada } \\
\text { terjadinya dukhul } \\
\text { (Pasal 153) }\end{array}$ & $\begin{array}{l}\text { Didasarkan atas } \\
\text { terjadinya akad bukan } \\
\text { dukhul. (Pasal } 88 \text { ) }\end{array}$ \\
\hline 15 & $\begin{array}{l}\text { Ihdad masa } \\
\text { berkabung }\end{array}$ & $\begin{array}{l}\text { Berlaku bagi istri } \\
\text { (Pasal 170) }\end{array}$ & $\begin{array}{l}\text { Suami juga dikenankan } \\
\text { baginya ihdad (Pasal } \\
112 \text { ) }\end{array}$ \\
\hline 16 & $\begin{array}{l}\text { Nusyusz } \\
\text { (hanya bagi } \\
\text { istri ) }\end{array}$ & $\begin{array}{l}\text { Hanya dimungkinkan } \\
\text { oleh istri (Pasal 84) }\end{array}$ & $\begin{array}{l}\text { Bisa dimungkinkan } \\
\text { oleh suami (Pasal } \\
53(1) .\end{array}$ \\
\hline 17 & $\begin{array}{l}\text { Khulu' atau } \\
\text { perceraian } \\
\text { atas inisiatif } \\
\text { istri }\end{array}$ & $\begin{array}{l}\text { Khuluk dinyatakan } \\
\text { sebagai thalaq bain } \\
\text { sughro, sehingga } \\
\text { tidak boleh rujuk } \\
\text { melainkan harus } \\
\text { nikah ulang.( Pasal }\end{array}$ & $\begin{array}{l}\text { Khuluq dan thalaq } \\
\text { adalah sama sehingga } \\
\text { boleh rujuk (thalaq } \\
\text { raj'iy) (Pasal } 1 \text { dan 59) }\end{array}$ \\
\hline
\end{tabular}




\begin{tabular}{|l|l|l|l|}
\hline & & $119)$ & \\
\hline 18 & Rujuk & $\begin{array}{l}\text { Hanya dimilki suami } \\
\text { (Pasal 163) }\end{array}$ & $\begin{array}{l}\text { Suami dan istri } \\
\text { memiliki hak untuk } \\
\text { rujuk (Pasal 105) }\end{array}$ \\
\hline
\end{tabular}

\section{Hukum Kewarisan}

\begin{tabular}{|c|l|l|l|}
\hline No & Pembahasan & KHI Inpress 1991 & CLD-KHI \\
\hline 1 & $\begin{array}{l}\text { Waris beda } \\
\text { agama }\end{array}$ & $\begin{array}{l}\text { Beda agama } \\
\text { Penghalang waris } \\
\text { mewarisi (Pasal 171) }\end{array}$ & $\begin{array}{l}\text { Beda agama bukan } \\
\text { penghalang proses } \\
\text { waris-mewarisi (Pasal } \\
\text { 2) }\end{array}$ \\
\hline 2 & $\begin{array}{l}\text { Anak diluar } \\
\text { nikah }\end{array}$ & $\begin{array}{l}\text { Hanya memilki } \\
\text { hubungan waris dari } \\
\text { ibunya, sekalipun } \\
\text { ayah biologisnya } \\
\text { sudah diketahui } \\
\text { (Pasal 186) }\end{array}$ & $\begin{array}{l}\text { Jika diketahui ayah } \\
\text { biologisnya anak tetap } \\
\text { memilki hak waris dari } \\
\text { ayah biologisnya } \\
\text { (Pasal 16) }\end{array}$ \\
\hline 3 & Awl dan radd & $\begin{array}{l}\text { Dipakai (Pasal 192 } \\
\text { dan 193) }\end{array}$ & Dihapus \\
\hline 4 & $\begin{array}{l}\text { Warisan bagi } \\
\text { laki-laki dan } \\
\text { perempuan }\end{array}$ & $\begin{array}{l}1: 2= \\
\text { perempuan:laki-laki }\end{array}$ & $\begin{array}{l}\text { 1:1 atau 2:2 , pria dan } \\
\text { wanita sama }\end{array}$ \\
\hline
\end{tabular}

\section{Pandangan Hakim PA Tentang Perumusan CLD-KHI}

\section{Konsep CLD-KHI Memilki Semangat Liberalisasi Hukum}

Dalam hal ini Ahmad Zuhdi selaku hakim di PA Yogyakarta mengatakan bahwa meskipun hakim diseluruh pengadilan agama menggunakan hukum Islam, tetapi dalam hal ini kita para hakim harus mengetahui bahwa hukum di Indonesia menganut sistem civil low, bukan common law, walaupun sejatinya hakim bukan corong 
undang-undang, tetapi hakim dalam hal ini menempatkan hukum tertulis pada garda terdepan. ${ }^{13}$

Berkaitan dengan dirumuskannya CLD-KHI Ahmad Zuhdi memberikan pandangannya bahwa:

CLD-KHI adalah sebuah pemahaman dan perumusan hukum keluarga Islam yang baru, yang dirumuskan oleh para alimulama, dosen-dosen, dan guru besar. Dalam hal ini mereka memilki pengetahuan keilmuan yang banyak dan sangat berpengaruh. CLD-KHI adalah pemahaman baru yang memungkinkan untuk dijadikan hukum dan berkembang. Hakim tidak akan menentang hal itu menjadi hukum materil. Akan tetapi sepanjang hal itu hanya sebatas wacana, maka kami tidak akan banyak berkomentar, karena hanyalah sebuah doktrin. setelah saya pelajari CLD-KHI, gagasan yang mereka rumuskan bagus, akan tetapi semangat mereka adalah semangat liberasi walaupun kita mengetahui di dalamnya ada unsur-unsur keadilan dan kesamaan gender, tetapi hal ini tidak bisa diterima oleh masyarakat umum

\section{Konsep CLD-KHI Tidak Relevan Dengan Sosiologis Masyarakat.}

Dalam hal ini Marwoto selaku hakim di Pengadilan Agama Sleman, beliau berpendapat bahwa perubahan-perubahan dalam masyarakat tentu saja dihadapakan kepada tradisi dan pemikiran yang sudah mapan, tetapi tidak menutup kemungkinan bahwa bisa saja hal tersebut dapat menimbulkan konflik, ataupun sebaliknya membuat kemashlahatan. Begitupun dengan dirumuskannya CLD-KHI sebagai draft dan tandingan bagi KHI, tidak semua kalangan masyarakat dapat menerimanya. Dalam hal ini beliau mengatakan:

Secara Prinsip ide dan gagasan dari CLD-KHI bagus, akan tetapi secara sosiologis masyarakat Indonesia belum bisa menerima. Perubahan hukum dan dinamika sosial dalam masyarakat memunculkan gagasan dan rumusan yang baru. Kami selaku

${ }^{13}$ Ahmad Zuhdi, Hakim PA Yogyakarta, Wawancara di Yogyakarta, tanggal 13- 
hakim Pengadilan Agama beranggapan bahwa konsep yang ditawarkan CLD-KHI memilki implikasi terhadap masyarakat walaupun tidak semua pasal menyimpang dari kaidah. Secara hukum tata negara kami selaku hakim tidak bisa menerapkan sebagai hukum materil. Hal ini berdampak dengan dibekukannya CLD-KHI oleh menteri agama Maftuh Basuni. Hakim yang ada di Pengadilan Agama masih terikat dengan KHI, walaupun secara tekhnis KHI bukanlah rujukan satu-satunya. Di antara ide dan gagasan yang tidak bisa diterima yaitu masih adanya unsurunsur liberal misalnya kawin kontrak, mengapa CLD-KHI melegalkan kawin kontra dan mengharamkan poligami, bukankah demikian melanggar kaidah Islam. Tidak ada di dalam CLD-KHI maqashid syari'ah yang di ajarkan yaitu memelihara (1) agama (2) akal pikiran (3) kehormatan (4) keturunan (5) harta benda. ${ }^{14}$

\section{KHI Inpres Telah Menjamin kemaslahatan.}

Statment di atas adalah yang penjelasan dari dua hakim di Pengadilan Agama Bantul, yaitu Yuniati Faizah dan Akhbaruddin. Dalam hal ini mereka menjelaskan bahwa ide pembentukan KHI berasal dari kalangan elit pemegang kekuasaan yaitu eksekutif dan yudikatif. Ide ini dilatarbelakangi oleh adanya problem tekhnis yustisial di Pengadilan Agama. KHI dibentuk melibatkan banyak pihak mulai dari hakim, pengacara, notaris, akademisi, Departemen Kehakiman, ulama, tokoh masyarakat, cendikiawan muslim dan sebagainya. Penyusunan KHI melibatkan berbagai pendekatan yang pastinya merujuk kepada Al-Quran dan sunnah, sehingga kami menganggap bahwa KHI yang selama ini kami pakai sebagai hukum materil sudah cukup baik. Lebih lanjut lagi Yuniati mengatakan bahwa:

Secara pribadi konsep ini telah bertentangan dengan keyakinan kami, kami meragukan apa yang dirumuskan oleh Musdah Mulia. Hal ini berkaitan protes dari masyarakat Indonesia sehingga MUI

${ }^{14}$ Marwoto, Hakim PA Sleman, wawancara di Sleman, tanggal 04 Juli 2014 
menulis surat kepada Mentri Agama untuk membekukan CLDKHI. Hukum Islam (KHI) dirumuskan oleh sekian banyak ulama, sehingga kecil kemungkinan untuk terjadi konflik. Secara teknis aplikasi KHI dalam kesehariannya tidak ada problem yang memberatkan. Dasar pijakan yang digunakan CLD-KHI tidak sesuai dengan kaidah Islam, walaupun KHI baru bersifat Inpres sebagai hukum materil tetapi hakim tidak memperdebatkannya. Secara umum hampir semua rumusan yang di tawarkan oleh CLD-KHI memilki perbedaan yang sangat signifikan, dan sangat berbeda dengan Kaidah-kaidah hukum islam. Bagaimana mungkin perempuan dapat menikahkan dirinya sendiri sedangkan di dalam al-Quran jelas (la-nikaha illa biwaliyyin). Prinsip-prinsip yang ditawarkan bukalah sebuah pembaharuan hukum Islam, melainkan sebuah penyelewengan dan penyesatan hukum. ${ }^{15}$

\section{Pandangan Hakim Terhadap Pendekatan CLD-KHI}

\section{Pendekatan CLD-KHI Berangkat Dari Kasus Bukan Normal Umum.}

Ahmad Zuhdi menjelaskan tentang pendekatan kasus yang digunakan oleh Tim PUG yang melakukan studi lapangan di Sulsel, Sumbar, Jabar, Aceh, dan NTB. Beliau mengatakan:

Sekilas dari melihat mater CLD-KHI pendekatan yang mereka gunakan adalah berangkat dari kasus tidak dari normal umum. Maka apabila hukum yang akan diterapkan hanya berangkat dari satu titik pastinya tidak merata. Setiap basis kasus yang mereka digunakan, pastinya memilki beragam penyelesaian. Mungkin bisa daerah tersebut masih kental dan patuh atas hukum adat, dan begitupun mungkin bisa daerah tersebut sudah menghilangkan corak hukum adatnya. Misalnya daerah Sumbar, yang notabene wanita memberikan mahar. Padahal sebenarnya hal itu adalah pengahantar, tetap laki-laki yang memberikan. Daerah Aceh yang masih sangat kental keIslamannya, pastinya

${ }^{15}$ Akbaruddin dan Yuniati Faizah, Hakim PA Bantul, wawancara di bantul, tanggal 28 Maret 2014. 
hukum-hukum syari'ah masih berlaku. Pertanyaan yang tersbesit dibenak hakim apa latar belakang dan alasan tempat-tempat itu dijadikan obyek penelitian kasus hukum. ${ }^{16}$

\section{Konsep HAM Dan Pluralisme Yang Dirumuskan Tidak Sesuai dengan Konteks Al-Qur'an.}

Marwoto menjelaskan bahwa setiap pendekatan-pendekatan yang dipakai dalam studi Islam mengandung makna dan nilai di dalamnya. Sekalipun makna tersbut tidak semuanya mengetahui, hanya kelompok-kelompok tertentu yang mengetahui, jelasnya mereka yang merumuskan.

Mengenai konsep HAM yang dipakai dalam metodologi pendekatan CLD-KHI Marwoto menjelaskan bahwa :

Konsep tentang HAM sangat dianjurkan dalam Islam. HAM merupakan modal dasar bagi perwujudan keadilan di tengah masyarakat. HAM juga menjamin setiap anggota masyarakat dapat hidup, merdeka bebas dan bertanggung jawab. Akan tetapi setiap konsep pastinya mempunyai batasan-batasan yang tidak bisa diterapkan secara total. Islam mengajarkan HAM bertindak dalam segala aspek kehidupan, tetapi pastinya setiap tindakan tersebut ada kadar-kadar dan norma-norma yang harus dipatuhi, sehingga rasionalitas tidak menjadi tuhan dalam menentukan jalan hidup. HAM yang bisa diterima oleh masyrakat adalah HAM yang masih terikat dengan syariat dan kaidah-kaidah Islam. ${ }^{17}$

Hak Asasi Manusia (HAM) adalah merupakan hak dasar yang melekat pada diri manusia. HAM didasarkan pada prinsip fundamental bahwa semua manusia mempunyai martabat yang inheren tanpa memandang jenis kelamin, warna kulit, bahasa, asal-usul bangsa, umur, kelas, keyakinan politik dan agama. Mereka semua dapat

\footnotetext{
Mei-2014

${ }^{16}$ Ahmad Zuhdi, Hakim PA Yogyakarta, Wawancara di Yogyakarta, tanggal 13-

${ }^{17}$ Marwoto, Hakim PA Sleman, wawancara di Sleman, tanggal 04 Juli 2014
} 
menikmati hak-haknya. Sedangkan menurut PBB, HAM adalah universal, indiviable, interdidependent, interrelated. ${ }^{18}$

\section{Pandangan Hakim Terhadap Materi CLD-KHI}

\section{Materi CLD-KHI Masih Mengandung Hukum Perdata BW.}

Berangkat dari pembahasan sebelumnya disini penulis akan menjelaskan bagaimana pandangan hakim di Pengadilan Agama Yogyakarta terhadap materi yang ada di dalam CLD-KHI. Dalam hal ini Ahmad Zuhdi selaku hakim Pengadilan Agama Yogyakarta menjelaskan bahwa :

Di dalam materi CLD-KHI terdapat pembaharuan pemahaman yang diangkat melalui beberapa pendekatan. Seperti gender, HAM, demokrasi, pluralisme, nasionalitas, dan kemaslahatan. Tetapi mengapa di dalam CLD-KHI inspirasinya masih mengandung hukum perdata umum, inspirasi yang muncul dari barat. Apalagi CLD-KHI masih diluar sistem hukum dan baru sekedar wacana. Di dalamnya terdapat ketentuan yang sudah dibatalkan dalam UU perkawinan 1974, yang menyatakan bahwa perkawinan hanyalah dalam hubungan keperdataan saja. Ketentuan seperti ini telah dihapus oleh undang-undang Perkawinan dan tidak dimunculkan di dalam KHI. Maka hal ini akan memunculkan bahwa CLD-KHI tidak terdapat nilai-nilai agama yang terkandung di dalamnya, dan merupakan produk barat yang sangat liberal. ${ }^{19}$

\section{Materi CLD-KHI Tidak Mencerminkan Maqâshid asy-Syarîah}

Pada pembahasan ini Marwoto selaku hakim di Pengadilan Agama Sleman memberikan pandangannya tentang materi CLD-KHI yaitu :

Materi yang disampaikan CLD-KHI baik dari segi hukum, walaupun secara sosiologis masyarakat Indonesia belum bisa

${ }^{18}$ Beni Setiawan, HAM dan Transformasi Sosial, Jurnal Asy-Syar'ah, (Vol.38 No 1 2004), h. 3.

${ }^{19}$ Ahmad Zuhdi, Hakim PA Yogyakarta, Wawancara di Yogyakarta, tanggal 13Mei-2014 
menerima. Di dalam draft yang di rumuskan terdapat pasal yang menjamin kemaslahatan. Misalnya pasal tentang Pencatatan Perkawinan, pasal tentang batasan minimimal usia nikah, pasal tentang nusyuz, pasal-pasal tersebut sekiranya menjamin kemashalahatan masyarakat. Tetapi di dalamnya juga terdapat pasal yang membingungkan dan jauh dari nilai-nilai agama. pasal-pasal tersebut melenceng dari apa yang telah diajarkan oleh agama. Inilah yang membuat masyarakat tidak bisa menerima secara utuh draf CLD-KHI yang berakibat di bekukannya oleh mentri agama maftuh basuni. Maka saya menyimpulkan bahwa di dalamnya tidak terdapatmaqâshid asysyarîah $^{20}$

Hakim Pengadilan Agama tidak menafikan bahwa rumusan pembaharuan yang dibentuk Tim PUG CLD-KHI dapat merubah konstruksi pemikiran dan tatanan kehidupan masyarakat. Suatu citacita yang diinginkan oleh semua pihak dan terealisasi. Tetapi yang terjadi malah sebaliknya ternyata CLD-KHI masih memerlukan banyak evaluasi bersama. Kehadirannya belum bisa memberikan suatu problem solving yang paling tepat pada kasus-kasus yang berkenaan dengan hukum keluarga. Banyak pihak menganggap materi yang disampaikan tidak Islamis. ${ }^{21}$

\section{Peran Otonomi Akal Telah Melewati Ketentuan Syari'ah.}

Gambaran peran otonomi akal disampaikan oleh Yuniati dan Akhbaruddin, senada dengan apa yang mereka sampaikan pada pembahasan sebelumnya bahwa Yuniati Menyatakan:

Di dalam CLD-KHI tidak terdapat pemahaman baru yang menjadikan draft tersebut layak diangkat menjadi Undangundang yang menjadi tandingan KHI. Kami berpikir semua itu hanyalah permainan orang-orang liberal. Apabila Tim PUG mau mengubah draft atau pasal yang ada di dalam KHI, maka

${ }^{20}$ Marwoto, Hakim PA Sleman, wawancara di Sleman, tanggal 04 Juli 2014

${ }^{21}$ Nur Muhammad Kassim, Optimalisasi Pembaharuan Hukum Islam Dalam Bingkai Metodologis Counter Legal Draft, lihat di Jurnal al-manahij, Vol. VI NO. 2, Juli 2012, h. 245. 
alangkah lebih baik apabila mereka mengubah Undang-Undang Perkawinan 1974 sebagai langkah awal alam dalam proses pembaharuan hukum Islam. Peranan otonomi akal yang mereka mainkan sebagai bentuk kebebasan berpikir telah melewati dari garis-garis ketentuan syari'ah. Bagaimana hakim dapat meyakini bahwa materi yang disampaikan menjamin kebaikan dan kemashlahatan. Apabila mereka memberikan pengertian bahwa pernikahan adalah mua'malah dan bukan ibadah. Pada pasal pembukaannya sudah menyalahi aturan, apalagi pasal-pasal berikutnya. ${ }^{22}$

\section{Pandangan Hakim Terhadap Pasal-Pasal CLD-KHI.}

\section{Pelaksanaan Perkawinan}

Di dalam KHI pada Bab II telah dijelaskan bahwa pernikahan menurut hukum Islam adalah akad yang sangat kuat atau mitsaaqon ghaliizhan untuk menaati perintah Allah dan melaksanakannya merupakan ibadah. ${ }^{23}$ Tujuan dari perkawinan disini adalah perwujudan ketaatan kepada Allah. Berbeda dengan yang dijelaskan oleh CLD-KHI pada Bab II pasal 2 yaitu, perkawinan adalah akad yang sangat kuat atau mitsaaqon ghaliizhanyang dilakukan secara sadar oleh seorang laki-laki dan seorang perempuan untuk membentuk keluarga yang pelaksanaannya didasarkan pada kerelaan dan kesepakatan kedua belah pihak. ${ }^{24}$ Tujuan dari perkawinan menurut CLD-KHI hanya hubungan sosial antara laki-laki dan perempuan tetapi tidak dengan sang pencipta, dalam arti kata lain hubungan itu hanya sebatas di dunia dan bersifat keperdataan.

Dalam hal ini Ahmad Zuhdi berpendapat tentang perihal perkawinan yang dijadikan sebagai mua'malah oleh Tim PUG :

Pernikahan adalah ibadah, hubungan ini tidak hanya sebatas di dunia tetapi juga di akhirat. Ketika Tim PUG menyatakan

\footnotetext{
${ }^{22}$ Akbaruddin dan Yuniati Faizah, Hakim PA Bantul, wawancara di bantul, tanggal 28 Maret 2014.

${ }^{23}$ Kompilasi Hukum Islam, (Jakarta, Media Wacana, 2010), h. 144.

${ }^{24}$ Tim Pengarusataman Gender, Pembaruan Hukum Islam Counter Legal Draft Kompilasi Hukum Islam, ( Jakarta, Depag RI, 2004), h. 36.
} 
mua'malah sama saja bagi mereka mempermainkan hukum tuhan. Apabila hal ini dijadikan mua'malah sama saja artinya mereka akan merubah semua tatacara, rukun nikah, syarat dan sunnah-sunnahnya, yang terjadi peraturan tentang pernikahan akan berubah sekehendak hatinya. ${ }^{25}$

\section{Pencatatan Perkawinan.}

Pencatatan nikah bukan termaksuk rukun perkawinan melainkan hanya persyaratan atau kewajiban administratif. Hal ini dijelaskan pada pasal 5 (1) yang menyebutkan bahwa : pertama, Agar terjamin ketertiban perkawinan bagi masyarakat Islam setiap perkwinan harus dicatat, kedua, pencatatan perkawinan tersebut harus dilakukan oleh pegawai pencatat nikah sebagaimana diatur dalam Undang-undang No 22 tahun 1946 jo undang-undang No 32 tahun $1954 .^{26}$

Hal ini sangat berbeda dengan yang ada pada CLD-KHI, pencatatan nikah merupakan rukun perkawinan, sehingga perkawinan tidak sah jika tanpa catatan. Pencatatan memporeh perhatian utama CLD-KHI, karena dua alasan. Pertama berlandaskan pada dalil analogi hukum (qiyas analogy). Jika dalam al-Quran surat al-baqoroh ayat 282, hutang yang melibatkan dua orang saja wajib dicatatkan, maka apalagi perkawinan sebagai peristiwa hukum yang berimplikasi terhadap nasb (kekerabatan), kewarisan, dan status sosial. Jika dalam pandangan KHI-inpress hanya menjadi persyaratan administratif, maka dengan ketentuan CLD-KHI hal ini menjadi sebuah rukun. Kedua, berdasarkan dalil, sadd- al-dzariah (menutup jalan terjadinya kerusakan) perkawinan yang tidak dicatatkan menyebabkan tidak adanya perlindungan hukum bagi perempuan dan anak. Status perkawinan dan kekerabatan dalam pembagian harta waris juga sulit dibutuktikan. Oleh karena itu sesuai dengan tujuan perkawinan maka pernikahan harus dicatatkan dan menjadi rukun di dalammnya. ${ }^{27}$

\footnotetext{
${ }^{25}$ Ahmad Zuhdi, Hakim PA Yogyakarta, Wawancara di Yogyakarta, tanggal 13Mei-2014

${ }^{26}$ Kompilasi Hukum Islam, (Jakarta, Media Wacana, 2010), h. 144.

${ }^{27}$ Tim Pengarusataman Gender, Pembaruan Hukum Islam Counter Legal Draft Kompilasi Hukum Islam, ( Jakarta, Depag RI, 2004), h. 5.
} 
Pada pasal inilah yang membuat Ahmad Zuhdi bertanya-tanya, apakah yang menjadi gerangan Tim PUG untuk menjadikan pencacatan nikah sebagai rukun di dalamnya,?, bukankah di satu sisi kebiasaan orang-orang sekuler ingin menafikan peran negara kedalam peran agama, tetapi pada hal ini mereka ingin negara ikut terlibat dalam peran agama. Inilah yang merubah mainstrem pemikiran mereka. Mereka ingin menjadikan keterlibatan negara dalam peran agama karena alasan-alasan yang telah disampaikan, tetapi mengapa mereka menjadikan pernikahan sebagai hubungan mua'malah semata, bukan karena ibadah dan perintah dari Allah. Lebih lanjut Ahmad Zuhdi menjelaskan bahwa :

Secara sosiologis pencatatan nikah yang mereka usung menjadi sebuah kemashlahatn tetapi disisi lain mereka memisahkan dan melepaskan diri dari hukum agama. inilah yang menjadi permasalahan besar. Sejatinya setiap orang yang ingin berijitihad, seharusnya mensinkronkan dengan konteks quran bukan sebaliknya. ${ }^{28}$

\section{Batas Minimal Usia Perkawinan.}

Selaras dengan pemikiran KHI tentang batas usia perkawinan, Ahmad Zuhdi menjelaskan bahwa :

Ini adalah suatu pemikiran(doktrin), maka apa yang menjadi pertimbangan CLD-KHI mematok hal tersebut, padahal di masa rosululoh aisyah menikah masih usia rendah. Apakah hal ini dapat menjamin kesetaraan bagi laki-laki dan perempuan, dan apakah hal ini dapat menjamin tidak terjadi pernikahan dini. Pada saat ini kasus dispensasi nikah diseluruh PA booming dan merebak, anak-anak umur 14 dan 16 tahun banyak melakukan hamil diluar nikah. Bagaimana nantinya nasib anak-anak di Indonesia yang telah hamil di luar nikah, apabila CLD-KHI mematok hal demikian!. Saya sebagai hakim sah-sah saja untuk

${ }^{28}$ Akbaruddin dan Yuniati Faizah, Hakim PA Bantul, wawancara di bantul, tanggal 28 Maret 2014 
diterapkan tetapi saya tidak menjamin apa dampak yang terjadi kedepannya. ${ }^{29}$

Senada dengan pemikiran Ahmad Zuhdi, Marwoto Menjelaskan bahwa:

Masalah umur bukan sesuatu yang prinsip, selama hal itu menuju kemashalahatan. Artinya dengan usia dewasa bisa berpikir lebih dewasa. Dengannya pernikahan bisa dipertanggung jawabkan, silahkan saja tetapi semua itu ada pintu-pintu daruratnya. Hakim saat ini sangat dilematis karena dahulu anak pacaran hamil ketika tamat SMA, sedangkan saat ini tamat SMP sudah meminta dipensasi nikah. Maka idealnya kalau permasalahan itu tidak pernah ada, hakim sangat setuju 19 tahun laki-laki dan perempuan, atau bahkan 21 atau 22 tahun. Permasalahan ini harus dilakukan dengan kerja sama antar tokoh agama, pemuda-pemudi dan masyarakat, sebab kita dalam posisi dilematis. ${ }^{30}$

Konsep-konsep di atas ternyata lebih menginspirasi Mudara, dengan tegasnya Mudara mengungkapkan:

Usia pernikahan sebaiknya lebih ditingkatkan menjadi 19 tahun atau bahkan 21 tahun, inilah yang akan menjadi PR kita semua bagaimana meminimalisir pernikahan dini dan hamil di luar nikah. Usia di bawah 19 tahun belum mempunyai bekal yang cukup matang untuk membangun sebuah keluarga. ${ }^{31}$

Hasil penelitian Pusat Studi Wanita UIN (PSW) Jakarta pada tahun 2000 mengungkapkan temuan menarik yakni bahwa rata-rata usia ideal perempuan untuk menikah berkisar 19 tahun - 24 tahun. Yang penting dicatat bahwa kematangan usia tersebut idealnya berupa akumulasi kesiapan fisik, ekonomi, sosial, mental, kejiawaan, agama, dan budaya. Batas usia minimal dalam pernikahan antara laki-laki dan

${ }^{29}$ Ahmad Zuhdi, Hakim PA Yogyakarta, Wawancara di Yogyakarta, tanggal 13Mei-2014

${ }^{30}$ Marwoto, Hakim PA Sleman, wawancara di Sleman, tanggal 04 Juli 2014

${ }^{31}$ Mudara, Hakim PA Wonosari, wawancara di Wonosari, tanggal 07 Juli 2014 
perempuan adalah 20 tahun. Dalam hal ini tidak perlu ada perbedaan antara keduanya. ${ }^{32}$

\section{Mahar Dalam Perkawinan}

Statment tentang mahar ternyata tidak banyak disinggung oleh para hakim. Sejatinya hakim-hakim yang penulis wawancarai telah sepakat dengan apa yang telah disyariat oleh hukum Islam. Mahar di dalam Islam adalah pemberian calon suami kepada calon istri,Allah memerintahkan kepada mereka untuk memberikan mahar kepada wanita/istri sebagai pemberian suka rela. Perintah ini merupakan kewajiban. Dan kalau si istri berbaik hati, memberikan secara ikhlas dari mahar tersebut, baik sebagian atau malah seluruhnya, maka suami/wali boleh memakannya dengan penuh kelahapan dan berharap makanan tersebut akan membawa akibat baik. Hal ini telah diterangkan di dalam al-Quran: (an-nisa ayat 4).

Inilah yang menjadi dasar para hakim untuk tidak sependapat dengan yang diusulkan oleh CLD-KHI, bahkan para hakim bertanyatanya tentang dasar penetapatan mahar yang diusulkan oleh CLD-KHI. Begitu mudahnya Tim PUG ini menjadikan 'illat pemberian mahar sebagai pembelian terhadap wanita seperti yang telah diterangkan sebelumnya. Mereka menyandarkannya pada diskriminasi wanita yang sejatinya tidak semua laki-laki berniat demikian.

\section{Nikah Beda Agama.}

Salah satu pasal krusial yang ada di dalam CLD-KHI adalah tentang nikah beda agama. Dalam hal ini tidak hanya kalangan pemikir, dan ulama yang frontal akan pendapat tersebut, tetapi masyarakat umum pun miris akan hal tersebut. Begitupun dengan hakim-hakim yang penulis wawancarai, tidak satupun dari mereka yang senada dengan pemikiran CLD-KHI.Dari penjelasan-penjelasan di atas maka jelaslah para hakim sangat menentang adanya praktek nikah beda agama, disamping mendasarkannya pada al-Quran surat al-Baqoroh ayat 22 dan al-Mumtahanah ayat 10.

${ }^{32}$ Musdah Mulia, Muslimah Reformis, (Bandung, Mizan Pustaka, 2005), h. 375-376. 
Dua ayat di atas telah menjelaskan tentang pengharaman nikah beda agama, walaupun sampai sekarang masih menimbulkan banyak perdebatan dari kalangan pemikir tentang tafsiran ayat-ayat masingmasing. Dalam hal ini Ahmad Zuhdi menyampaikan komentarnya :

Tujuan perkawinan tidak akan tercapai bagi dua insan yang melakukan kawin bada agama. Secara religius jelas mereka memiliki prinsip yang berbeda dalam menjalankan ajaran agamanya ( ibadah ) masing-masing. Secara psikologis anak yang dibesarkan akan mengalami kebimbangan dalam memilih agamanya nanti. Maka tidaklah ada kemaslahatn di dalamnya ${ }^{33}$.

Begitupun yang disampaikan dengan Yuniati Faizah yang lebih mengedapankan tentang psikologis perkembangan anak, ia menuturkan

Sebagai hamba Allah yang taat alangkah lebih baik kita memilih pasangan yang seiman dan seakidah dengan kita. Seperti apa jadinya pendidikan agama anak-anak kedepannya, apakah kita menerapkan konsep kerelaan dengan mereka,?, padahal di satu sisi kita meyakini Islamlah yang terbaik. Apabila kita melepaskan ia untuk memilih, maka sama halnya kita menjerumuskan ia ke dalam neraka. ${ }^{34}$

Alasan-alasan di atas menjadikan para hakim tetap meyakini bahwa pernikahan beda agama dilarang dalam Islam, dan tidak ada padanya unsur kemaslahatan. Bahkan Ikhsanuddin mengatakan apakah setiap pasal yang telah ditetapkan CLD-KHI menjadi acuan bagi mereka sendiri. Apakah sejatinya ketika keluarga mereka dihadapkan dengan hal ini misalnya anak mereka, setujukah mereka apabila anak mereka menikah dengan pasangan yang bukan muslim,?. Hidup dalam keluarga yang tidak seakidah dan seiman, sehingga melahirkan anak-anak yang nantinya tidak tahu akan memilih siapa.

\section{Mei-2014}

${ }^{33}$ Ahmad Zuhdi, Hakim PA Yogyakarta, Wawancara di Yogyakarta, tanggal 13-

${ }^{34}$ Akbaruddin dan Yuniati Faizah, Hakim PA Bantul, wawancara di bantul, tanggal 28 Maret 2014 


\section{Iddah Dalam Perkawinan.}

Beragam komentar yang timbul dari para hakim tentang konsep Iddah yang diusulkan oleh CLD-KHI. Dalam hal ini Iddah terbagi ke dalam dua yaitu, Iddah (masa tunggu), dan Iddah (waktu tunggu akibat perceraian). Iddah dijelaskan pada pasal $153 \mathrm{KHI}-I n p r e s$ bahwa hal tersebut hanya berlaku pada istri yaitu : "bagi seorang istri yang putus perkawinannya berlaku waktu tunggu atau iddah, kecuali qabla aldukhul dan perkawinannya putus bukan karena kematian suami. ${ }^{35}$ "

Hal ini berbeda pada CLD-KHI pasal 88 bahwa hal tersebut berlaku bagi suami dan istri yaitu,"bagi suami dan istri yang perkawinannya telah dinyatakan putus oleh pengadilan agama berlaku masa transisi atau iddah. ${ }^{36} \mathrm{Hal}$ ini didasari karena prinsip persamaan gender yang diusulkan oleh CLD-KHI terhadap suami dan istri, sehingga mewajibkan keduanya untuk melakukan iddah.

Dalam hal ini penulis akan membahas secara umum tentang konsep iddah menurut pandangan hakim, terlepas dari pembagian iddah tersebut. Dasar disyariatkannya iddah dalam al-Quran yaitu iddah bagi wanita yang ditalak suami al-Baqoroh ayat 228, dan Bagi Seorang Istri yang Suaminya Meninggal Dunia, al-Baqoroh ayat 234.

Pada masalah ini tidak banyak hakim yang berkomentar, bahkan sebagian hakim pun mengiyakan apa yang telah dikonsepkan oleh CLD-KHI, misalnya Ahmad Zuhdi, ia menuturkan :

Saya setuju terhadap konsep ini, apabila alasan dari hal ini untuk keadilan dan kemaslahatan, walaupun masih terdapat semangatsemangat liberalisasi dan gender yang sangat kuat. ${ }^{37}$

Hal ini senada dengan komentarnya Marwoto yang menuturkan bahwa hal ini sudah berlaku di KUA.

Suami tidak bisa serta merta melakukan pernikahan, dan KUA tidak akan memberikannya. Alasannya karena pernah terjadi penyuludupan poligami. Di mana suami cerai dan langsung

${ }^{35}$ Kompilasi Hukum Islam, (Jakarta, Media Wacana, 2010), h.180.

${ }^{36}$ Tim Pengarusataman Gender, Pembaruan Hukum Islam Counter Legal Draft Kompilasi Hukum Islam, ( Jakarta, Depag RI, 2004), h. 65

${ }^{37}$ Ahmad Zuhdi, Hakim PA Yogyakarta, Wawancara di Yogyakarta, tanggal 13Mei-2014 
menikah dan dalam masa iddah itu suami rujuk dengan istri pertama. Dalam masalah ini hakim tidak bisa menolak dia karena dalam masa iddah. Dalam hal ini KUA lebih mengetahui dari pada hakim di Pengadilan Agama, dan lama iddah suami juga sama pada istrinya. ${ }^{38}$

Berbeda halnya dengan Marwoto dan Ahmad Zuhdi, Barwanto dan Iksanuddin yang mengatakan bahwa konsep iddah tidak tepat bila diberlakukan pada suami, iddah adalah masa tenggang seorang istri untuk menjaga kebersihan rahimnya dan bukan pada suami. Akan tetapi demi menjaga perasaan terhadap keluarga istri hendaknya suami mengerti dan memahami tanpa perlu disuruh atau ditetapkan peraturan seperti yang diterapkan CLD-KHI. Pendapat di atas senada dengan statmennya Yuniati Faizah, Mudara dan Akbaruddin.

\section{Pembagian Warisan (Laki-Laki Dan Perempuan)}

Dalam hal ini Marwoto menjelaskan konsep warisan yang terjadi pada kasus yang ada di peradilan agama, ia menuturkan :

Hal ini dikalangan hakim tidak terlalu sakral dan prinsip yang intinya pembagian warisan cenderung kepada konsep muamalah. Mediasi adalah jalan yang dikedapankan, mereka dituntut untuk bermusyawarah. Sesekali waktu boleh menggunakan hukum Islam, atau mereka memakai konsep musyawarah di dalam mediasi. ${ }^{39}$

Berbeda halnya dengan Barwanto dan Iksanuddin yang lebih mengedepankan konsep hukum Islam, walaupun mereka tidak menafikan adanya musyawarah di dalam mediasi. Dalam hal ini Ikhsanuddin menjelaskan bahwa:

Pembagian warisan 2:1 di dalam al-Quran telah seimbang dan selaras. Laki-laki mendapat dua bagian hal ini berdasarkan suami adalah kepala keluarga, di tangannyalah nasib keluarga. Sedangkan perempuan mendapat satu bagian hal ini berdasarkan istri ditanggung oleh suami. Perkara laki-laki lebih kaya dari

\footnotetext{
${ }^{38}$ Marwoto, Hakim PA Sleman, wawancara di Sleman, tanggal 04 Juli 2014

${ }^{39}$ Marwoto, Hakim PA Sleman, wawancara di Sleman, tanggal 04 Juli 2014
} 
perempuan adalah persoalan pribadi keluarga tersebut, dan tidak perlu di rumuskan ke dalam sebuah pembaruan hukum. ${ }^{40}$

Dalam hal ini Syahrur memberikan statmentnya bahwa pembagian warisan tidak dapat dipandang tidak adil dan diskriminatif terhadap kaum perempuan ataupun superioritas kaum laki-laki. Ia mengatakan ayat-ayat warisan hanyalah merupakan ayat-ayat hududiyah yang memberikan prinsip-prinsip tentang batas maksimum (al-hadd al-a'la) dan batas minimum (al-hadd al-adna) dalam pembagian warisan. Menurutnya ayat terssebut menegaskan bahw batas minimun bagi perempuan adalah separoh dari apa yang diterima laki-laki. Sementara laki-laki hanya dapat menerima bagian warisan maksimal dua kali lipat dari apa yang diterima perempuan. Diantara dua batas tersebut, para ulama dipersilahkan berijtihad sesuai dengan kondisi ekonomi, tanggung jawab keluarga, dan keterlibatan perempuan dalam memikul tanggung jawab keluarga yang berkembang, sesuai dengan tempat dan waktu tertentu. Intinya tidak lebih tinggi dari batas maksimum dan tidak lebih rendah dart batas minimum. ${ }^{41}$

\section{Penutup}

Hasil penelitian para hakim menyatakan bahwa CLD-KHI sejatinya masih terdapat prinsip-prinsip yang tidak sesuai dengan alQur'an dan Hadis, di antaranya :pertama konsep tersebut masih memilki semangat liberalisasi, kedua konsep tersebut tidak sejalan dengan sosiologi masyarakat, ketiga KHI telah menjamin kemaslahatan, keempat Umat Islam Indonesia Bermazhab Syafi'i, kelima CLD-KHI tidak sejalan dengan kebudayaan Bangsa. Konsep pendekatan studi Islam yang direncanakan oleh Tim PUG untuk merumuskan CLD-KHI sangat tidak sesuai. Semua berkaitan dengan lima prinsip di antaranya : pertama pendekatan cld-khi berangkat dari kasus bukan normal umum. Kedua ham dan pluralisme yang

${ }^{40}$ Barwanto dan Ikhsanuddin, Hakim PA Wates, wawancara di wates, tanggal 12 Juli 2014

${ }^{41}$ M. In'am Esha, M.Syahrur: Teori Batas, dalam, A. Khudori shaleh, (ed), Pemikiran Islam Kontemporer, (Yogyakarta, Jendela, 2003), h. 293 
dirumuskan tidak sejalan dengan konteks al-quran. Ketiga Kesetaraan Gender Telah Ditemukan Di dalam KHI. Keempat gender, HAM, Demokrasi, Pluralisme Dan Nasionalisasi Telah Terbungkus Di Dalam KHI, dan Berada di belakang Pemikiran para Hakim. Kelima pentingnya Keadilan Dalam Semua Konsep Pendekatan Studi Islam. CLD-KHI bukanlah sebuah pembaruan hukum atau modernisasi hukum, melainkan sebuah liberalasi hukum. Hal ini berdasarkan atas empat prinsip di antaranya: pertama Materi CLD-KHI masih mengandung hukum perdata BW, Kedua Materi CLD-KHI tidak mencerminkan maqoshidu syari'ah, Ketiga Peran otonomi akal telah melewati ketentuan syari'ah, Keempat Tidak mencerminkan kepatuhan terhadap Allah SWT. Faktor KHI yang baru bersifat Inpres, mazhab syafi'i yang mendominasi di Indonesia, serta CLD-KHI yang masih bersifat wacana sangat yang mempengaruhi pandangan hakim terhadap CLD-KHI.

\section{DAFTAR PUSTAKA}

Abdurrahman, Kompilasi Hukum Islam, Jakarta: CV Akademika Presindo, 1992

al-Mandari, Syafinuddin, Pluralisme Agama dan Masa Depan Masyarakat Sipil Di Indonesia, Jurnal Al-Huda, Vol 2, no 72002.

Ali, Zainudin, Sosiologi Hukum (Jakarta: Sinar Grafika, 2006)

Ali, Zainuddin, Hukum Islam Pengantar Ilmu Hukum Islam di Indonesia, Cet. 1. Jakarta: Sinar Grafika, 2006

Azizy, Qodri, Elektisisme Hukum Nasional, Yogyakarta, Gama Media, 2006

Az-zuhaili, Wahbah, al-fiqh al-islami wa-adilatuh, 1409H/1989 M, Beirut-Lubnan: Dar- al-fikr

Bahri, Syamsul, Metodologi Hukum Islam, Yogyakarta, Teras, 2008

Bahri, Syamsul, Metodologi Hukum Islam, Yogyakarta, Teras, 2008 
Cansil, Pengantar ilmu Hukum dan Tata Hukum Indonesia, cet.ke-2 Jakarta: Balai Pustaka, 1989

Departemen Agama RI, KompilasiHukum Islam di Indonesia (Jakarta :DirjenBinbaga Islam 1998

Hadikusuma, Hilman, Pengantar Ilmu Hukum Adat Indonesia, Bandung, Mandar Maju, 2003

Hafidz, Ahmad, Meretas Nalar Syariah Konfigurasi Pergulatan Akal Dalam Pengkajian Hukum Islam, Yogyakarta, Teras, 2011

Huzaimah dan Hafiz Anshary (ed), Problematika Hukum Islam Kontemporer, (Jakarta, LSIK, 1999

Junaedi, Mahfud, Ilmu Pendidikan Islam Filsafat dan Pengembangannya, Semarang, Rasail Media Group, 2010

Mulia, Musdah, Muslimah Reformis, Bandung, Mizan Pustaka, 2005

Muttaqien, Dadan dkk, Peradilan Agama dan Kompilasi Hukum Islam Dalam Tata Hukum Indonesia, Yogyakarta, UII Press, 1999

Mudzhar, M. Atho', Membaca Gelombang Ijtihad: Antara Tradisi dan Liberalisasi,Yogyakarta, Titian Ilahi Press, 1998.

Nasution, Khoiruddin, Hukum Keluarga Perdata Islam Indonesia, Yogyakarta, ACAdeMIA-Tazzafa, 2010

Nasution, Khoiruddin, Hukum Perdata Islam Indonesia dan Perbandingan Hukum Perkawinan Di Dunia Muslim, Yogyakarta, Tazzafa Acedemia, 2010

Proyek Pembinaan Badan Peradilan Agama, Kompilasi Perundangundangan Badan Peradilan Agama, Jakarta, Depag, 1981

Putra, Haidar, Sejarah Pertumbuhan Dan Pembaruan Pendidikan Islam Di Indonesia, Jakarta, Prenada Media Group, 2007

Rahardjo, Satjipto, Ilmu Hukum, Bandung, Citra aditya Bakti, 2006 
Rumadi, Marzuki wahid, Fiqh Madzhab Negara : Kritik atas Politik Hukum Islam di Indonesia, Yogyakarta: LKIS, 2001

Rahnema, Ali (ed), Para Perintis Zaman Baru Islam, Bandung, Mizan, 1996

Rahardjo, M. Dawam, Islam Dan Transformasi Budaya, Yogyakarta, Dhana Bakti Prima Yasa, 2002

Roqib, Moh, Pendidikan Perempuan, Purwokerto, Gama Media, 2003)

Rukiyati, dkk, Pendidikan Pancasila, Yogyakarta, UNY press , 2008

Rahardjo, Satjipto, Sosiologi Hukum dan perkembangan Metode dan Pilihan Masalah, Yogyakarta, Genta Publishing, 2010

Perkawinan Islam Indonesia, Yogyakarta, Mitra Utama, 2011

Wawancara dengan Ahmad Zuhdi hakim di PA Yogyakarta

Wawancara dengan Marwoto Hakim PA di Sleman

Wawancara Akbaruddin dan Yuniati hafizah, Hakim PA di bantul

Wawancara dengan Barwanto dan Ihksanuddin Hakim Pengadilan Agama Wates

Wawancara dengan Mudara Hakim di Pengadilan Agama Wonosari 